\title{
EFEKTIVITAS PROBLEM SOLVING THERAPY MENGURANGI STRES DAN MENINGKATKAN KEMAMPUAN PROBLEM SOLVING PADA WANITA YANG PERNAH MENGALAMI KEKERASAN DALAM RUMAH TANGGA
}

\author{
Mulia Marita Lasutri Tama \\ Dosen Universitas Bina Darma \\ Jalan Jenderal Ahmad Yani No. 3 Palembang \\ Sur-el: lia chuky@yahoo.com
}

\begin{abstract}
The purpose of this study is to design a therapy module and determine the therapeutic effectiveness of Problem Solving Therapy which is an approach based on cognitive behavior that focuses on training attitudes and effective problem solving skills. The approach used in this study is a mixed method that involves collecting qualitative and quantitative data. Qualitative data used in this study are interviews, observations, and daily report self-problems, while the quantitative data are in the form of DASS questionnaires (Depression, Anxiety, Stress Scale) and Problem Solving Test. The results showed that there were significant differences between the results of the pre test and post test. In addition, there are also changes in the cognitive, emotional and behavioral areas, such as subjects who are able to think positively about the day-to-day situations, events, and problems so that they also affect the emotions and behavior of subjects such as subjects more calm and more able to control his emotions when facing situations, events, and everyday problems. Thus the therapy used in this study is Problem Solving Therapy effective for reducing stress and improving problem solving abilities in individuals who have experienced domestic violence.
\end{abstract}

Keywords: Problem Solving Therapy, Stress, Domestic Violence

\begin{abstract}
Abstrak : Tujuan dari penelitian ini yaitu untuk merancang modul terapi dan mengetahui efektivitas terapi dari Problem Solving Therapy yang merupakan suatu pendekatan yang berbasis pada cognitive behavior yang berfokus pada pelatihan sikap dan keterampilan penyelesaian masalah yang efektif. Pendekatan yang digunakan dalam penelitian ini yaitu mixed methods yaitu melibatkan pengumpulan data kualitatif dan kuantitatif. Data kualitatif yang digunakan dalam penelitian ini yaitu wawancara, observasi, dan self report daily problem, sedangkan data kuantitatifnya yaitu berupa kuesioner DASS (Depression, Anxiety, Stress Scale) dan Problem Solving Test. Hasil penelitian menunjukkan bahwa terdapatnya perbedaan yang signifikan antara hasil pre test dan post test. Selain itu juga terdapat perubahan pada area kognitif, emosi dan perilaku, seperti subjek sudah bisa berfikir positif terhadap situasi, kejadian, dan masalah sehari-hari yang dialaminya sehingga hal ini juga berpengaruh pada emosi dan perilaku subjek seperti subjek lebih bersikap tenang dan lebih bisa mengontrol emosinya ketika menghadapi situasi, kejadian, dan masalah sehari-hari. Dengan demikian terapi yang digunakan dalam penlitian ini yaitu Problem Solving Therapy efektif untuk mengurangi stres dan meningkatkan kemampuan problem solving pada individu yang pernah mengalami kekerasan dalam rumah tangga.
\end{abstract}

Kata Kunci : Problem Solving Therapy, Stress, Kekerasan Dalam Rumah Tangga

\section{PENDAHULUAN}

Dalam menjalani kehidupan manusia tidak akan terlepas dan terhindar dari stres. Stres merupakan suatu fenomena yang tidak dapat dielakkan dari kehidupan seseorang, baik yang masih muda maupun yang tua pasti pernah mengalami stres, dimana saja, dalam setiap situasi dan itu merupakan hal yang wajar. Stres diketahui salah satu fenomena yang mendapatkan perhatian besar dalam bidang psikologi. Hal ini dikarenakan 
adanya banyak masalah psikologis yang bersangkut paut dengan stres.

Stres adalah sebagai suatu hubungan yang khas antara individu dan lingkungan yang dinilai oleh individu tersebut sebagai suatu hal yang mengancam atau melampaui kemampuannya untuk mengatasinya sehingga membahayakan kesejahteraannya (Lazarus dan Folkman, 1984). Menurut Feldman (1989), stres adalah proses yang menilai suatu peristiwa sebagai sesuatu yang mengancam, menantang, membahayakan dan individu merespon peristiwa itu pada level fisiologis, emosional, kognitif dan perilaku.

Sumber stres adalah kejadian atau lingkungan yang menimbulkan perasaanperasaan tegang (Smet, 1994). Lazarus (1976), mengatakan bahwa sumber stres itu terbagi dua yaitu, stresor eksternal (berasal dari luar individu) dan stresor internal (berasal dari dalam individu). Turner dan Helms (1995) berpendapat bahwa stresor adalah kejadian eksternal dan internal yang mempengaruhi keseimbangan individu yang dapat membuat individu berada dalam keadaan emosi tertekan.

Stres tidak selalu berdampak negatif bagi individu yang mengalaminya, stres dapat menimbulkan dampak positif. Kedua dampak ini tergantung dari bagaimana individu mengartikan stresor yang dihadapinya. Powel (1983) menguraikan dampak positif dan negatif dari stres. Adapun dampak positif dari stres yaitu (1) memuaskan kebutuhan dasar individu untuk memperoleh stimulasi sepanjang hidupnya (Zuckerman dalam Powell, 1983).

Kemampuan menangani masalah, jika individu dapat menangani masalah yang dihadapinya, maka akan tertantang untuk menguasai hal-hal lain yang lebih sulit. (3) Stress inoculation, induvidu akan lebih tahan menghadapi stres jika sebelumnya sudah bisa mengatasi situasi yang menyebabkan stres. Sedangkan dampak negatif dari stres yaitu (1) gangguan fisik dan emosi, yang merupakan yang paling jelas terlihat, seperti, sakit jantung, tekanan darah tinggi, mudah marah, mudah tersinggung. (2) Penurunan efektifitas dalam bekerja dan dalam hubungannya dengan orang karena terlalu sibuk menghadapi tekanan-tekanan yang dialami, menyisakan sedikit energi untuk bekerja dan juga mempertahankan hubungan yang baik dengan orang lain. (3) Penurunan energi untuk menyesuaikan diri. Menurut Selye (dalam Powell, 1983), upaya menanggulagi stres membuat individu menguras energi sehingga jika dimasa yang akan datang ia menghadapi stres lain, ia tidak memiliki energi yang cukup untuk mengatasinya.

Stres disebabkan oleh berbagai macam faktor, salah satu faktor yang sering menimbulkan gangguan stres adalah 
peristiwa - peristiwa dalam rentang kehidupan, salah satunya adalah kekerasan yang merupakan sumber penyebab stres. Kekerasan dapat terjadi dimana saja baik di dalam rumah tangga maupun di dalam lingkungan sosial. Adapun bentuk kekerasan yang paling sering terjadi adalah kekerasan terhadap istri atau yang lebih tepat kekerasan terhadap perempuan oleh pasangan intimnya. Kekerasan terhadap perempuan yang dilakukan oleh pasangan intimnya tersebut dikenal dengan istilah "kekerasan dalam rumah tangga". Kekerasan dalam rumah tangga merupakan setiap perbuatan yang dilakukan seseorang atau beberapa orang terhadap orang lain yang berakibat atau mungkin berakibat kesengsaraan atau penderitaan secara fisik, seksual dan psikologis, termasuk ancaman perbuatan tertentu, pemaksaan atau perampasan kemerdekaan secara sewenang-wenang atau penekanan secara ekonomis yang terjadi dalam lingkup keluarga.

Kekerasan dalam rumah tangga adalah setiap perbuatan yang dilakukan seseorang atau beberapa orang terhadap orang lain, yang berakibat atau mungkin berakibat kesengsaraan atau penderitaan secara fisik, seksual, dan atau psikologis, termasuk ancaman perbuatan tertentu, pemaksaan atau perampasan kemerdekaan secara sewenang- wenang atau penekanan secara ekonomis yang terjadi dalam lingkup rumah tangga (Sukri, 2004).

Kekerasan dalam rumah tangga dapat mengakibatkan efek jangka pendek maupun jangka panjang bagi korban termasuk perempuan dan anak-anak. Kekerasan ini bisa membawa dampak bagi kesejateraan fisik maupun psikis perempuan. Secara fisik perempuan bisa menderita luka, cacat permanen bhkan sampai meninggal. Secara seksual dapat terjadi kehamilan yang tidak diinginkan, keguguran dan bahkan kemungkinan tertular penyakit menular seksual (Komnas Perempuan, 2002). Sedangkan secara psikologis, menurut Walker (dalam Hoff, 1990), perempuan akan memiliki harga diri yang rendah, mereka merasa tidak adekuat mempersespsikan diri mereka tidak sesuai dengan harapan yang seharusnya ditampilkan seorang perempuan, sehingga mereka cenderung menerima hukuman dari suami dan cenderung menyalahkan diri sendiri. Selain itu terjadi penyangkalan, mereka menyangkal sudah dipukuli, dan mengingkari apa yang terjadi pada mereka. Selain itu kekerasan yang terjadi berulang-ulang dapat menyebabkan perempuan menjadi pasif, dan mengembangkan learned helplessness (kehilangan keyakinan akan kemampuan untuk keluar dari suatu keadaan) karena tidak menemukan jalan keluar sehingga mereka percaya bahwa setiap tindakan yang 
diambil akan memperburuk situasi. Jika kekerasan terhadap perempuan ini berlangsung berkepanjangan, maka akan memunculkan simptom-simptom Post Traumatic Stress Disorder (PTSD) seperti depresi, insomnia, kecemasan, penurunan minat, dan konsentrasi bahkan akan sangat memungkinkan muncul keinginan untuk bunuh diri ataupun membunuh suaminya sebagai tindakan membela diri (Komnas, 2002).

Berbagai tindakan kekerasan yang dialami oleh perempuan tentunya akan membawa dampak yang membahayakan terhadap kesejahteraan fisik maupun psikis perempuan. Oleh karena itu perlu dilakukan suatu intervensi atau penanganan yang tepat bagi korban kekerasan dalam rumah tangga. Adapun bentuk intervensi yang dapat dilakukan atau diberikan pada korban yang mengalami kekerasan dalam rumah tangga yaitu dengan melakukan konseling dan terapi, misalnya dengan cognitive therapy, rational emotive behavior therapy, dan cognitive behavior therapy. Pada penelitian ini, memfokuskan pada suatu pendekatan yang positif dalam intervensi klinis yang berbasis pada pendekatan cognitive behavior yang berfokus pada pelatihan sikap dan keterampilan pemecahan masalah yang efektif yaitu problem solving therapy karena disesuaikan dengan kasus subjek penelitian. Selain itu dikarenakan problem solving therapy merupakan suatu pendekatan bukan hanya fokus pada pengembangan keterampilan individu tetapi juga fokus pada pengalaman emosi individu.

Problem solving therapy adalah pendekatan yang positif terhadap intervensi klinis yang berbasis pada pendekatan cognitive behavior yang berfokus pada pelatihan sikap dan keterampilan pemecahan masalah yang efektif (D'Zurilla \& Nezu dalam Dobson, 2010). Tujuan umum dari problem solving therapy untuk mengurangi psikopatologi, meningkatkan fungsi psikologis dan perilaku, dan untuk mengoptimalkan kualitas hidup individu (O’Donohue \& Fisher, 2008).

Dalam berbagai studi yang telah dilakukan oleh Dzurilla \& Nezu (dalam O’Donohue \& Fisher, 2008), problem solving therapy merupakan suatu intervensi yang sangat efektif untuk berbagai masalah psikologis seperti depresi, stres, gangguan penyesuaian, gangguan kecemasan umum, keinginan bunuh diri, kekurangmampuan keterampilan sosial pada penderita skizoprenia, masalah emosional, fobia sosial, masalah perilaku dan emosi individu yang mengalami retardasi mental, masalah penyimpangan seksual, penyalahgunaan zat, gangguan perilaku pada anak-anak. Hal ini dikarenakan problem solving therapy merupakan suatu pendekatan bukan hanya fokus pada pengembangan keterampilan 
individu tetapi juga fokus pada pengalaman emosi individu, sikap dan keyakinan inidividu.

Ada beberapa tahapan dalam melaksanakan dan menerapkan problem solving therapy yaitu : pelatihan orientasi masalah positif dan pelatihan rational problem solving yangterdiri dari beberapa tahapan seperti identifikasi masalah dan mendefinisikan masalah, mencari alternatif solusi, pengambilan keputusan dan implementasi solusi dan evaluasi.

$$
\text { Beberapa tahapan dalam }
$$

melaksanakan dan menerapkan problem solving therapy yaitu pelatihan orientasi masalah positif dengan menggunakan teknik kognitif dan relaksasi, kemudian tahap selanjutnya yaitu pelatihan rational problem solving dengan mengajarkan dan memberikan pelatihan keterampilan pemecahan masalah yang efektif dengan mengajarkan langkah - langkah dalam menerapkan rational problem solving yaitu mengajarkan cara mengidentifikasi dan mendefinisikan masalah, mengajarkan cara mencari alternatif solusi, mengajarkan cara mengambil keputusan dan lalu kemudian mengimplementasikan solusi ke dalam kehidupan nyata dan evaluasi.

Dari berbagai hasil studi dan penelitian menyatakan bahwa problem solving therapy efektif untuk menangani masalah-masalah klinis seperti stres, depresi, kecemasan, masalah pernikahan, masalah emosi dan perilaku pada individu yang mengalami retardasi mental dan masalah penyesuaian sosial.

\section{METODOLOGI PENELITIAN}

Pendekatan yang digunakan dalam penelitian ini yaitu mixed method approach. Pendekatan campuran dimana peneliti melibatkan pengumpulan data kualitatif dan kuantitatif baik secara bersamaan atau berurutan untuk mendapatkan pemahaman yang lebih baik terhadap suatu masalah. Peneliti mengumpulkan, menganalisis dan mengintegrasikan baik data kuantitatif maupun data kualitatif dalam sebuah studi tunggal maupun dalam berbagai bentuk penelitian lainnya

Pada penelitian ini strategi yang digunakan yaitu sequential, di mana peneliti berusaha untuk menguraikan atau memperluas temuan dari suatu metode dengan metode lainnya. Data kualitatif yang digunakan pada penelitian ini yaitu wawancara, untuk mengetahui latar belakang subjek dan awal terjadinya masalah pada subjek dan wawancara selama pelaksanaan terapi, observasi untuk melihat perilaku subjek sehari-hari selama pengambilan data dan pelaksanaan terapi, dan self report yang berupa daily problem yaitu untuk melihat masalah atau kejadian yang dialami subjek sehari-hari dan bagaimana penilaian dan 
perilaku subjek terhadap kejadian tersebut. Sedangkan data kuantitatifnya yaitu berupa kuesioner yaitu problem solving test dan depressioan, anxiety, stress scale (DASS).

Desain yang digunakan dalam penelitian ini yaitu single case kuasi experiment dengan desain A-B. Single case difokuskan pada pemeriksaan terhadap perubahan perilaku pada seorang individu atau paling banyak, beberapa orang individu. Kuasi ekperimen merupakan alternatif penting bila ekperimen sejati tidak mungkin dilakukan. Desain A-B yaitu suatu pengulangan pengukuran perilaku atau target behavior pada sekurang-kurangnya dua kondisi yaitu kondisi baseline (A) dan kondisi intervensi (B). Prosedur utama yang ditempuh dalam desain $\mathrm{AB}$ meliputi pengukuran target behavior pada fase baseline dan setelah datanya stabil intervensi mulai diberikan. Selama fase intervensi target behavior secara kontinyu dilakukan pengukuran sampai mencapai data yang stabil. Pada desain AB ini tidak ada replikasi (pengulangan) pengukuran, dimana fase beseline (A) dan intervensi (B) masingmasing dilakukan hanya sekali untuk subjek yang sama.

\section{HASIL DAN PEMBAHASAN}

Berdasarkan hasil penelitian dapat dilihat bahwa problem solving therapy efektif untuk 66 mengurangi gejala-gejala depresi, kecemasan, dan stres pada individu yang pernah mengalami kekerasan dalam rumah tangga. Hal ini sesuai dengan pendapat D'Zurilla and Nezu (2007) bahwa problem solving therapy efektif untuk mengatasi permasalahan-permasalahan psikologis termasuk diantaranya depresi, kecemasan, keinginan bunuh diri, masalah emosi dan stres, dengan pendekatan perawatan yang pendek mulai dari 6 sesi atau lebih dari 12 minggu tergantung dengan jenis permasalahan dan tingkat keparahan individu.

Pada penelitian ini keberhasilan terapi dilihat dengan melihat perbandingan antara hasil pre test dan post test yang diukur dari hasil kuesioner problem solving test dan depression anxiety stress scale. Hal ini sesuai dengan pendapat D'Zurilla and Nezu (dalam O'Donohue \& Fisher, 2008) bahwa problem solving therapy efektif untuk mengurangi gejala-gejala emosi negatif dan meningkatkan kemampuan problem solving sehingga akan dapat meningkatkan kualitas hidup inidividu atau kesejahteraan inidvidu. Selain itu juga keberhasilan terapi dapat dilihat dengan melihat perbandingan kondisi subjek sebelum dan sesudah mengikuti terapi berdasarkan hasil wawancara mengenai aspek kognitif, emosi dan perilaku.

Pada aspek kognitif, subjek merasakan bahwa ia senantiasa untuk 
menerapkan berfikir positif terhadap situasi, kejadian, orang lain dan diri sendiri dalam kehidupan sehari-harinya. Hal ini dikarenakan ia belajar dan menerapkan konsep terapi kognitif dalam kehidupan sehari-hari yang mulanya memang tidak mudah untuk menerapkannya tapi lama kelamaan ia belajar dan terus belajar akhirnya ia bisa memunculkan pikiran otomatis positif dengan sendirinya, sehingga dalam menghadapi situasi, kejadian, masalah sehari-hari ia lebih cenderung untuk bersikap dan berperilaku positif. Hal ini sesuai dengan pendapat Beck (2011), bagaimana seseorang bersikap dan merasakan emosi terhadap suatu situasi atau kejadian dipengaruhi oleh bagaimana mereka mempersepsikan lingkungannya.

Perubahan kognitif yang terjadi pada subjek, mempengaruhi bagaimana ia bersikap dan berperilaku terhadap situasi, kejadian dan masalah yang ia hadapi. Selain itu kemampuan subjek untuk mengolah informasi yang diterima, membantunya merubah core belief yang pada akhirnya mempengaruhi emosi dan tingkah lakunya. Ada pun menurut Beck (2011), ketika subjek menyadari bahwa core belief yang dimilikinya adalah salah, maka akan lebih mudah untuk diubah. Begitu juga dengan subjek ketika ia menyadari bahwa core belief yang dimilikinya selama ini adalah salah, dan membuatya sulit untuk berubah atau bangkit dari keterpurukan. Hal ini tentunya sangat membantu kelancaran proses intervensi yang dilakukan.

Disamping itu juga, subjek menerapkan teknik visualisasi dan relaksasi ketika ia merasakan sesuatu yang tidak sesuai dengan yang ia harapkan atau inginkan sehingga ia menjadi lebih tenang dan rileks. Keberhasilan subjek menerapkan teknik kognitif, visualisasi dan relaksasi dalam kehidupannya sehari-hari tentunya membawa dampak perubahan pada aspek emosi dan perilakunya. Hal inilah yang menjadi fokus utama atau faktor awal dari problem solving therapy, yaitu subjek bisa bersikap positif terhadap situasi, kejadian, masalah dan diri sendiri yang ia hadapi sehingga ia bisa melaksanakan atau menyelesaikan permasalahan yang ia hadapi. Namun, ketika subjek belum memiliki sikap positif terhadap situasi, kejadian masalah atau diri sendiri maka masalah sulit untuk diselesaikan. Hal inilah yang terkadang menyebabkan individu tidak bisa terhindar dari stres yang berkepanjangan dan akhirnya menyebabkan gangguan psikologis yang lainnya (D'Zurilla \& Nezu, 2007).

Faktor lain yang mendukung keberhasilan terapi adalah keinginan subjek untuk dapat berubah. Seperti yang disampaikan oleh Rahmat (2001), salah satu faktor yang mempengaruhi problem solving adalah motivasi. Selain itu juga menurut 
Dzurilla \& Nezu (dalam O’Donohue \& Fisher, 2008), jika individu sudah memiliki sikap dan emosi yang positif maka individu tentunya memiliki motivasi yang pada gilirannya dapat memfasilitasi usaha pemecahan masalah yang adaptif. Begitu juga dengan subjek, yang mana ia sudah memiliki sikap dan emosi yang positif dalam menghadapi berbagai situasi, kejadian, dan masalah sehari-hari sehingga ia bisa menyelesaikan permasalahannya secara adaptif.

Selain motivasi yang ada pada diri subjek untuk berubah, dukungan dari keluarga juga memberikan dampak positif terhadap subjek. Hal inilah yang memperkuat subjek untuk berubah. Disamping itu, peneliti juga menggunakan percakapan kognitif dan media menonton video untuk memunculkan emotional insight subjek dan menyadari bahwa core belief yang selama ini dimilikinya adalah salah. Hal ini sesuai dengan pendapat Beck (1979) bahwa terapi kognitif efektif untuk menyadarkan bahwa pikiran-pikiran negatif atau core belief yang dimiliki oleh pasien adalah salah.

\section{SIMPULAN}

Berdasarkan hasil penelitian, maka dapat disimpulkan bahwa problem solving therapy efektif untuk mengurangi stres dan meningkatkan kemampuan problem solving 68 pada individu yang mengalami gejala-gejala depresi, anxiety, dan stres akibat kekerasan dalam rumah tangga. Efektifitas ini terlihat dari beberapa hal, diantaranya adalah dengan berkurangnya atau hilangnya gejala-gejala yang dialami subjek seperti depresi, cemas, stres, selain itu terdapatnya perubahan pada aspek kognitif, emosi dan perilaku pada subjek sebelum dan sesudah diberikan intervensi.

\section{Saran}

Saran yang dapat diberikan yaitu :

1. Untuk tenaga professional, dapat diketahui bahwa problem solving therapy dapat menjadi salah satu alternatif terapi dalam menangani masalah kekerasan dalam rumah tangga terutama untuk mengurangi dampak-dampak akibat kekerasan dalam rumah tangga.

2. Bagi subjek diharapkan untuk terus mempraktekkan teknik yang sudah dipelajari, sehingga dapat merasakan manfaatnya dalam jangka panjang. Subjek juga diharapkan untuk tetap melakukan kegiatan atau aktifitas yang berhubungan dengan orang lain sehingga ia melupakan kejadian-kejadian yang tidak menyenangkan sebelumya.

3. Bagi keluarga dan orang-orang terdekat subjek, diharapkan untuk tetap mendukung subjek dengan menciptakan dan menjaga suasana yang 
menyenangkan dan senantiasa untuk

selalu saling mendukung dan

mengingatkan agar tetap berfikir positif dalam menghadapi berbagai situasi, kejadian atau masalah sehari-hari yang dialami dan tetap menggunakan teknik yang sudah dipelajari pada saat terapi.

4. Bagi penelitian selanjutnya, perlu mempertimbangkan berbagai macam teknik dan media lainnya yang akan digunakan untuk mendukung penelitian atau proses terapi sehingga terapi dapat menjadi lebih singkat. 


\section{DAFTAR RUJUKAN}

Beck, A. (1979). Cognitive therapy of depression. New York : The Guilford Press

Beck, Judith. S. (2011). Cognitive behavior therapy : basic and beyond. $2^{\text {nd }} . e d$. Newyork : The Guilford Press

Dobson, K. (2010). Handbook of cognitive behavioral therapies. $3^{\text {rd }}$.ed. New York : The Guilford Press

D'Zurilla, T \& Nezu, A. (2007). Problem solving therapy : a positive approach to clinical intervention. $3^{\text {rd }}$.ed. New York : Springer Publishing Company

Feldman, R.S. (1989). Adjustment: applying in a complex world. New York : McGraw Hill

Hoff, L.A. (1990). Battered woman as survivors. London : Routledge Lazarus ,R dan Folkman, S. (1984). Stress, appraisal, coping. New York : Springer Publishing Company

Komisi Nasional Perempuan. (2002). Peta kekerasan pengalaman perempuan Indonesia. Jakarta : Ameepro

Lazarus, R. (1976). Pattern of adjustment. $3^{\text {rd }}$. ed. Tokyo: McGraw Hill Kogakusha

Lazarus, R.S \& Folkman, S. 1984. Stress appraisal and coping. Newyork : Springer Publishing Company.Inc.

O'Donohue, W \& Fisher, J. (2008). Cognitive behavior therapy. $2^{\text {nd }}$. ed. Canada : John Wiley \& Sons Inc

Powel, D.H. (1983). Human adjustment: normal adaptation trough the life cycle. Boston: Little Brown

Rahmat, Jalaluddin. (2001). Psikologi komunikasi. Bandung : PT. Remaja Rosdakarya

Smet, B. (1994). Psikologi kesehatan. Jakarta: PT Grasindo
Sukri, S. (2004). Islam menentang kekerasan terhadap istri.Yogyakarta: Gama Media

Turner, J.S. \& Helms, D.B. (1995). Lifespan development. $3^{\text {rd }}$.ed. New York : Holt, Rineheart \& Winston, Inc 